\title{
Measuring gaps between Tourists' Expectations and Perceptions with Reference to Cairo as a tourist destination
}

\author{
Nehal Eltayeb \\ Faculty of Tourism and Hotel Management \\ Tourism Department, Pharos University, Alexandria
}

\begin{abstract}
:
Customers generally have a tendency to compare the service they 'experience' with the service they 'expect'. If the perception does not match the expectation, there arises a gap, which could refer to a satisfaction or dissatisfaction. Tourist satisfaction is an important element due to its role in destination survival. This paper estimates the gaps between tourists' expectations and perceptions. It also identifies the differences among nationalities of tourists in their perception of services provided in Cairo as a tourist destination; also it determines the dependence of tourists' future behavioral intention on satisfaction or dissatisfaction of services. The results showed gaps between what tourists expect and what they perceive; also indicated a difference among nationalities in their perception .in addition it was found that the tourists' future behavioral intention is dependent on the services that meet tourists over all expectations.
\end{abstract}

Keywords: Destination and tourist product quality, tourist satisfaction, future behavioral intention

\section{Introduction}

Tourist satisfaction is one of the most relevant topics in the tourism and hospitality industry due to its role in the survival and future of any tourism product and service (Gursoy et al. 2007) as satisfied tourist will transform his experience to others and repeat his visit (Alien et.al, 2007). Tourist satisfaction is recognized as one of the key judgment that tourists use to measure a tourism service (Bowen and Clarke 2002). Yoon and Uysal (2005) suggested that tourist satisfaction is determined by the tourists' perceived disparity between the preferred and actual leisure experiences.

Thus, we can understand what drives tourists' satisfaction and makes Cairo an attractive destination and what makes a tourist willing to choose it among alternative destinations. That will enhance the tourist service and product quality provided(Armario,2008).

The Main objectives of this study are to:

1- Estimate the gaps between tourists' expectations and perceptions,

2-Identify the differences among nationalities of tourists in their perception of services provided in Cairo as a tourist destination;

3-determine the dependency of tourists' future behavioral intention on the satisfaction level of services provided in Cairo.

\section{Tourist's satisfaction:}

Lovelock et al. (2001) defined customer satisfaction as an individual's feeling of pleasure or disappointment resulting from comparing a product's perceived performance (or outcome) to his or her expectations as it is based on his her judgment that the product or service itself. Provides pleasurable consumption related fulfilment.

Satisfaction was defined as individual's cognitive affective state derived from a consumer experience (Bosque and Martin, 2008). Moreover, thinking about satisfaction is a process in which we think how to meet consumer expectations .Perceiving failure in delivering services leads to (stop) tourist response to return to the destination and (voice) influential in the choice of destinations for other tourists. This can be applied to the routine use of inadequate services, such as congested roads, late buses and poor security performance (East et al. 2008). 


\section{Tourists' expectation:}

There are two levels of expectations, desired and adequate. Berry and Parasuraman (1991) defined the level of service the customer hopes to receive as "the desired level", while the level of service that the customer finds at least acceptable is called "the adequate service level". According to this approach, customers carry two sets of expectations.

Tourists have expectations after selecting a destination for a holiday and that their satisfaction levels during and after their holiday period is functions of their expectations. Understanding tourists expectations will give important clues in developing destination attractiveness and improving tourist goods and service (Aksu et al. 2010) .

\section{The relationship between tourist satisfaction, expectation and perception:}

Service quality is determined by the customer's perceptions which result from comparing expectations that the customer has before receiving the service to the actual experience that the customer gets from the service delivery. If the expectations are met, the service quality will be described as satisfactory (Grönroos, 1983).

The absence of expected service can create dissatisfaction which will adversely impact on customer intention of future behavior whether to repurchase or recommend it (Cronin et al. 2000)

Gibson (2005) stated that the more satisfied the customer, the more the respetition his purchase of a product or service and will say positive words and recommend it to others. That means that it is necessary to identify the factors that could lead to customer satisfaction in order to fulfill it by creating good products or services.

\section{Future behavioral intention:}

Behavioral intention is different from behavioral expectations and willingness. Intention describes a human's plan to do a certain behavior ; behavioral expectation describes how people think they will probably behave in a certain situation, while willingness describes to what extent they are ready to act if an opportunity presents itself (Cugelman et al ., 2009).

Kuenzel and Katsaris (2009) illustrated that post-visit behavior has two dimensions: intention to return (purchase intention/loyalty) and recommendation to others through word-of-mouth (WOM).

Mahadzirah et.al (2012) suggested that the favorable behavioral intentions are associated with a service provider's ability to get its customers to: (1) Say positive things about them, (2) recommend them to other customers, (3) remain loyal to them, (4) spend more with them, and (5) pay price premiums.

According to Canny (2013) visitor retention is a key to the destinations profitability for most service providers, behavior is determined by a tourist's willing to perform or not to perform a subjective behavior.

\section{Destination and tourist product quality}

European Communities (2003) explained that "Qualities" is a tool for the Quality Performance Evaluation of tourist destinations and it should be used in destinations to evaluate its quality performance.

It has been clarified by Buhalis (2000) that the term destinations means places that offer a blend of tourism products and services, which are consumed under a brand name of the destination. Gyimothy (2000) stated that tourists perceive a tourism destination as an out of the ordinary, integrated experience or virtual product that only exists as a whole in their minds.

Furthermore, "it is well known that a destination can also be a perceptual concept, which can be subjectively interpreted by consumers, depending on their travel itinerary, cultural background, purpose of visit, educational level, and past experience" (Jafari 2000). However Weiermair (2000) observes that, although tourists experience plurality of individual service that they face during their visit at a tourist destination even though tourists experience a multitude of individual service encounters at a tourist destination and are able to evaluate their inherent qualities. What matters in the end most to them is the total experience during the destination

\section{Measuring destination quality:}

Tourist destinations' quality needs to be continuously improved for destination's success, if not to survive. To improve quality, current levels need to be measured to identify the areas that require improvement (Seakhoa, 2007). "Good quality 
service is not enough to cause tourism product quality perception, even though an excellent service may positively impress the consumer to make him or her close their eyes to shortcomings and defects experienced elsewhere in the tourism product. So, promoting quality in tourism and tourist products is a priority in different tourism activities" (Eraqi, 2006)

Factors for example like cleanliness, safety/security, transportation, people's hospitality, nature, professionalism of service, culture and attractions all impact tourist satisfaction; these factors should be given priority in the development of tourist products (Paunovic2014). Therefore the Destination is an area that should include all the services and provides what tourists consume during his visit (Terzibasoglu, 2004). Moreover Vengesayi (2003) identified that the more a destination is able to meet the needs of tourists, the more it is perceived to be attractive and the more the destination is likely to be chosen.

\section{Conceptual model and Research Hypotheses}

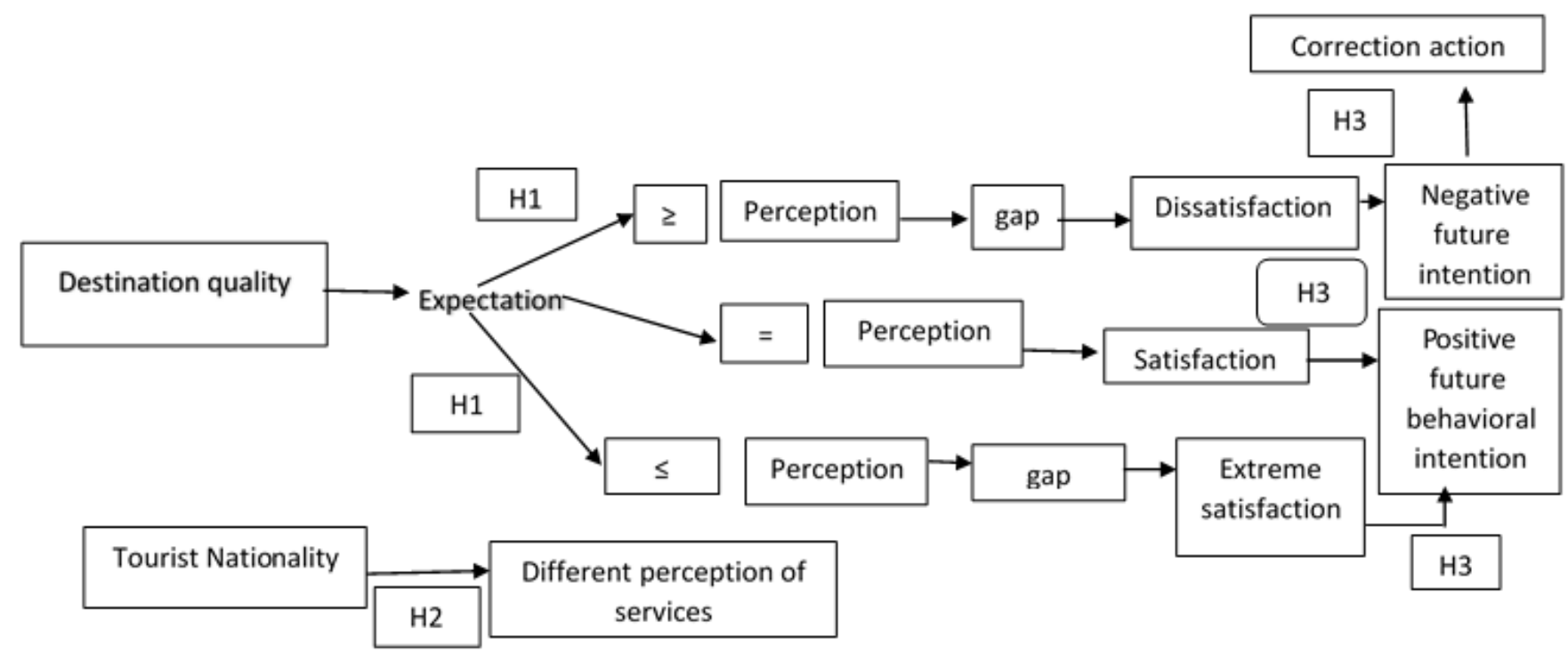

Shape ( 1 ) Conceptual model and Research Hypotheses

Hypotheses

$\mathrm{H} 1=$ There is a gap between what tourists' expected and what they perceived.

$\mathrm{H} 2=$ There is a difference among nationalities of tourists in their perception of services provided in Cairo as tourist destination.

$\mathrm{H} 3=$ the tourists' behavioral intention in the future is dependent on the satisfaction level with services provided in Cairo that meets overall expectation. 


\section{Research Methodology:}

A quantitative approach was employed using a questionnaire. The questionnaire was randomly submitted to a sample of 300 national and international tourists in Cairo between $1^{\text {st }}$ of March, 2015 and $10^{\text {th }}$ of August,. A pilot test was carried out among 40 tourists in order to enhance reliability and internal validity in well - known tourist spots and online. The questionnaire consists of 4 major sections, section 1 included questions about socio-demographic characteristics: gender, and nationality. Sections 2 concerned the Quality Performance of Cairo as a tourist Destination, i.e. to assess expectation before and perception after visiting the destination. Section 3 measures the overall tourists satisfaction, section 4 enquired about future behavioral intention whether to recommend the destination to others, say positive things about it, visit it in the future. A 5-point Likert scale was used. 300 respondents completed the questionnaire with a response rate of $75 \%$.

\section{RESULTS AND DISCUSSION:}

\section{Characteristics of the respondents:}

Table (1) Respondents' gender

\begin{tabular}{|c|c|}
\hline & Percent \\
\hline Male & 78.5 \\
female & 21.5 \\
Total & 100.0 \\
\hline
\end{tabular}

Table (2) respondents' nationalities

\begin{tabular}{|c|c|c|c|}
\hline & & Percent & $\begin{array}{c}\text { Cumulative } \\
\text { Percent }\end{array}$ \\
\hline \multirow{6}{*}{ Valid } & Arab & $29.2 \%$ & 29.2 \\
\hline & European & $29.2 \%$ & 58.5 \\
\hline & Fareast & $12.3 \%$ & 70.8 \\
\hline & American & $7.7 \%$ & 78.5 \\
\hline & Other & $21.5 \%$ & 100.0 \\
\hline & Total & $100 \%$ & \\
\hline
\end{tabular}

Most of the participants were Europeans (29.2\%), Arabs (29.2\%), followed by $12.3 \%$ living in the Fareast countries, $7.7 \%$ were Americans and $21.5 \%$ of the respondents were of other Countries as shown in table (2).

\section{Reliability and Validity analysis}

Measured items are considered reliable if Cronbach's alpha $(\alpha)$ is 0.6 or more. Table 3 shows reliability and validity measures. 
Table (3) Reliability and validity

\begin{tabular}{|l|c|c|}
\hline \multicolumn{1}{|c|}{ Dimensions } & reliability & validity \\
\hline Eating and drinking & 0.758 & 0.401 \\
\hline Transportation & 0.761 & 0.391 \\
\hline Accommodation & 0.758 & 0.472 \\
\hline Airport & 0.761 & 0.427 \\
\hline Accessibility for limited mobility & 0.766 & 0.366 \\
\hline Culture & 0.769 & 0.354 \\
\hline Value for money & 0.758 & 0.397 \\
\hline Pre-arrival communication & 0.766 & 0.376 \\
\hline Bathing water Qualities & 0.763 & 0.354 \\
\hline Information & 0.765 & 0.387 \\
\hline Local environment & 0.664 & 0.354 \\
\hline Ambient air quality & 0.764 & 0.364 \\
\hline Safety and security & 0.769 & 0.352 \\
\hline Quality of welcome & 0.762 & 0.359 \\
\hline Overall satisfaction & 0.774 & 0.353 \\
\hline Future Behavioral Intention & & 0.357 \\
\hline
\end{tabular}

Table3 indicates that the measured items are considered reliable a valid; the internal consistency among the items is Between 0.66 and 0.77 and the validity of the overall scale, Between 0.35 and 0.47. 


\section{Expectation-Satisfaction Analysis}

The following table (4) presents expectation, perception means for all measured items and gaps between them.

Table (4) Expectation-Satisfaction Analyses for Cairo as a tourist Destination

\begin{tabular}{|c|c|c|c|c|}
\hline Dimensions & Items & $\begin{array}{l}\text { Expectation } \\
\text { Mean }\end{array}$ & $\begin{array}{l}\text { Perception } \\
\text { Mean }\end{array}$ & Gap \\
\hline \multirow{6}{*}{$\begin{array}{l}\text { Eating and } \\
\text { drinking }\end{array}$} & Restaurants provide correct account lists & 3.6 & 2.49 & -1.11 \\
\hline & Variety and quality of places to eat and drink & 3.55 & 2.8 & -0.75 \\
\hline & food and beverages hygiene & 2.91 & 2.29 & -0.62 \\
\hline & Prices of food and beverages are convenient & 3.96 & 4.03 & 0.07 \\
\hline & Interaction with restaurant staff & 3.53 & 2.97 & -0.56 \\
\hline & $\begin{array}{l}\text { Restaurants provide food and beverage that } \\
\text { you used to have in your daily life }\end{array}$ & 2.57 & 2.46 & -0.11 \\
\hline & & & & -0.51 \\
\hline \multirow{5}{*}{ Transportation } & Accessibility to tourist attractions & 3.51 & 2.34 & -1.17 \\
\hline & Public transportation signs & 3.09 & 1.83 & -1.26 \\
\hline & Standard of transport services & 3.15 & 2.14 & -1.01 \\
\hline & Public transportation station exit signs & 2.79 & 2.14 & -0.65 \\
\hline & Interaction with taxi drivers & 2.94 & 2.45 & -0.49 \\
\hline & & & & -0.92 \\
\hline \multirow{6}{*}{ Accommodation } & Lodging facilities signs & 3.59 & 3.06 & -0.53 \\
\hline & Quality of accommodation & 3.6 & 2.57 & -1.03 \\
\hline & Friendliness of hotel staff & 3.68 & 3.49 & -0.19 \\
\hline & Hotel prices are convenient & 3.85 & 2.71 & -1.14 \\
\hline & $\begin{array}{c}\text { Hotel staff are willing to respond to your } \\
\text { request }\end{array}$ & 3.77 & 3.4 & -0.37 \\
\hline & Hotel rooms are Clean and hygienic & 3.72 & 2.89 & -0.83 \\
\hline
\end{tabular}




\begin{tabular}{|c|c|c|c|c|}
\hline & Discipline and flexibility of staff & 3.53 & 2.97 & -0.56 \\
\hline & & & & -0.66 \\
\hline \multirow{15}{*}{ Airport } & Speed check in to the airport & 3.7 & 2.46 & -1.24 \\
\hline & Speedy check out from the airport & 3.43 & 2.46 & -0.97 \\
\hline & $\begin{array}{c}\text { Accuracy of the answers you receive at your } \\
\text { request }\end{array}$ & 3.23 & 2.51 & -0.72 \\
\hline & $\begin{array}{c}\text { Problems due to lack of understanding of } \\
\text { language }\end{array}$ & 3.15 & 2.51 & -0.64 \\
\hline & Flight information Display system (FIDS) & 3.13 & 2.37 & -0.76 \\
\hline & Quality of public announcements & 3.47 & 3.55 & 0.08 \\
\hline & Terminal atmosphere/comfort & 3.43 & 3.63 & 0.2 \\
\hline & Terminal temperature/air conditioning & 3.74 & 3.69 & -0.05 \\
\hline & Cleanliness of restrooms & 3.38 & 3.06 & -0.32 \\
\hline & Overall attitude of staff & 3.67 & 3.37 & -0.3 \\
\hline & Staff appearance & 3.7 & 3.49 & -0.21 \\
\hline & Security/airport safety & 3.36 & 3.17 & -0.19 \\
\hline & Seating areas & 3.49 & 3.31 & -0.18 \\
\hline & Quality of food and beverage & 3.4 & 2.74 & -0.66 \\
\hline & Duty free level & 3.51 & 2.77 & -0.74 \\
\hline & & & & -0.45 \\
\hline \multirow{4}{*}{$\begin{array}{l}\text { Accessibility for } \\
\text { limited mobility }\end{array}$} & Doors are operated fully automatically & 3.4 & 2.6 & -0.8 \\
\hline & $\begin{array}{l}\text { Bus seats for limited mobility are next to the } \\
\text { entrance and exit doors and in close proximity } \\
\text { to the stopping place of the vehicle }\end{array}$ & 3.25 & 2.54 & -0.71 \\
\hline & $\begin{array}{l}\text { Almost step-free accessibility of toilets and } \\
\text { service areas with almost no thresholds and or } \\
\text { minimal.. }\end{array}$ & 2.85 & 2.51 & -0.34 \\
\hline & $\begin{array}{l}\text { Buses are equipped with handholds and other } \\
\text { gripping aids }\end{array}$ & 3.4 & 2 & -1.4 \\
\hline
\end{tabular}




\begin{tabular}{|c|c|c|c|c|}
\hline & $\begin{array}{l}\text { Stairs are a low step height to guarantee } \\
\text { accessibility }\end{array}$ & 3.25 & 2.17 & -1.08 \\
\hline & Ramps with handrails in the tourist sites & 3.19 & 2.14 & -1.05 \\
\hline & & & & -0.92 \\
\hline \multirow{5}{*}{ Culture } & the entertainment services and Arts provided & 3.7 & 3.8 & 0.1 \\
\hline & $\begin{array}{l}\text { the Behavioral patterns consistent with your } \\
\text { social habits }\end{array}$ & 3.51 & 2.8 & -0.71 \\
\hline & tourist services satisfy your motives and wants & 3.3 & 3 & -0.3 \\
\hline & $\begin{array}{l}\text { Inherited traditions of Egyptian society do not } \\
\text { prevent your enjoyment of visit. }\end{array}$ & 3.53 & 3.2 & -0.33 \\
\hline & There is cultural diversity in Cairo & 3.64 & 3.14 & -0.5 \\
\hline & & & & -0.35 \\
\hline $\begin{array}{c}\text { Value for } \\
\text { Money }\end{array}$ & Value for money in general & 3.68 & 3.37 & -0.31 \\
\hline $\begin{array}{l}\text { Pre-arrival } \\
\text { communication }\end{array}$ & $\begin{array}{c}\text { Expectations are regularly assessed via market } \\
\text { survey }\end{array}$ & 2.43 & 1.86 & -0.57 \\
\hline $\begin{array}{c}\text { Bathing water } \\
\text { Qualities }\end{array}$ & Cleanliness of bathing areas & 2.85 & 2.17 & -0.68 \\
\hline \multirow{7}{*}{ Information } & Availability of Tourist guide book & 2.94 & 1.83 & -1.11 \\
\hline & Tourist sign maps & 3.32 & 1.8 & -1.52 \\
\hline & Product signs in stores & 3.47 & 2.97 & -0.5 \\
\hline & Quality of information on things to do & 3.64 & 2.17 & -1.47 \\
\hline & Availability of pamphlet at each sightseeing & 3.72 & 2.06 & -1.66 \\
\hline & Promotion matches reality & 3.85 & 2.69 & -1.16 \\
\hline & $\begin{array}{l}\text { Lack of communication due to language } \\
\text { barrier }\end{array}$ & 3.34 & 2.69 & -0.65 \\
\hline & & & & -1.15 \\
\hline Local & Level of crowding & 2.87 & 2 & -0.87 \\
\hline
\end{tabular}




\begin{tabular}{|c|c|c|c|c|}
\hline environment & Cleanliness of the local environment & 2.7 & 1.57 & $\mathbf{- 1 . 1 3}$ \\
\hline $\begin{array}{c}\text { Ambient air } \\
\text { Quality }\end{array}$ & Quality of air in the destination & 2.89 & 2.17 & $\mathbf{- 1 . 0 0}$ \\
\hline $\begin{array}{c}\text { Safety and } \\
\text { Security }\end{array}$ & Feeling of security and safety & 3.08 & 2.8 & $\mathbf{- 0 . 2 8}$ \\
\hline $\begin{array}{c}\text { Quality of } \\
\text { Welcome }\end{array}$ & Friendliness of the local population & 3.7 & 4.14 & $\mathbf{0 . 4 4}$ \\
\hline
\end{tabular}

The difference between expectation and perception of tourist forms the gap score, which is then averaged for each dimension. Table (4) represents the gap score for tourists in Cairo. Tourists were dissatisfied with the following variables that formed many gaps as follows:

Gap1: information (-1.15) visitors' expectations versus perceptions: due to the lack of:

-availability of pamphlet at every sightseeing,

- Tourist sign maps,

- Quality of information on things to do,

- Promotion matches reality,

- Availability of Tourist guide book,

- Communication due to language problems

- Product signs in stores.

Gap 2: Local environment (-1.00) as a result of:

lack of Cleanliness of the local environment, and

high levels of congestion

Gap 3: Transportation (-0.92) as a result of:

- lack of Public transportation signs.

- lack of accessibility to tourist attractions.

- low standard of transport services.

- lack of public transportation station exit signs.

- Interaction with taxi drivers.

Gap 4: Accessibility to limited mobility (-0.92) for:

Stairs aren't of low step height to guarantee accessibility,

Lack of ramps with handrails at the tourist sites,

Buses aren't equipped with handholds and other gripping aids,

Doors aren't operated fully automatically, 
Lack of bus seats for limited mobility next to the entrance and exit doors and in close proximity to the stopping place of the vehicle, and

Almost step-free accessibility of toilets and service areas with almost no thresholds or minimal.

Gap 5: Ambient air quality (-0.72)

Gap 6: Bathing water qualities (-0.68) due to the lack of:

- Cleanliness of bathing areas.

Gap 7: accommodation (-0.66for:

Hotel prices aren't convenient,

Low Quality of accommodation

Hotel rooms are neither clean nor hygienic,

Lack of Discipline and flexibility of staff,

Lack of lodging facilities signs,

Hotel staffs aren't willing to respond to your request.

Friendliness of hotel staff,

Gap 8: Pre-arrival communication (-0.57) for:

Expectations aren't regularly assessed via market survey.

Gap 9: Eating and drinking (-0.51) for:

Restaurants provide in correct account lists;

Poor Variety and quality of places to eat and drink,

Lack of food and beverages hygiene

Interaction with restaurant staff

Restaurants don't provide food and beverage that you are used to have in your daily life

Gap 10: Airport (-0.45) for:

Low Speed of check- in and check -out at the airport,

Flight information Display system (FIDS)

Duty free level

Inaccuracy of the answers you receive up on your request.

Problems due to miscommunication.

Low Quality of food and beverage,

Lack of Cleanliness of restrooms

Terminal temperature/air conditioning,

Staff appearance

Lack of Security/airport safety.

Seating areas.

Gap 11: Culture (-0.35) for:

The Behavioral patterns being inconsistent with visitors' social habits,

Tourist services provided satisfy your motives and wants. 
Inherited traditions of Egyptian society do not prevent your enjoyment of visit

There is cultural diversity in Cairo.

Gap 12: Value for money $(-0.35)$

Gap 13: Safety and security $(-0.28)$ as result of:

Feeling of insecurity and unsafety.

The above mentioned supports hypothesis no 1 "there is a gap between what tourists' expected and what they perceived".

On the other hand the results indicated that tourists were satisfied with the following items:

Prices of food and beverages,

Quality of public announcements at the airport

level of Terminal atmosphere/comfort

entertainment services and Arts.

Friendliness of the local people

\section{Expectation-satisfaction grid:}

The following is an expectation-perception grid showing the overall ratings of tourists' perceptions of Cairo as tourist destination

\section{High expectation}

-Restaurants provide correct account lists.

- Accessibility to tourist attractions.

- Public transportation signs.

- Quality of accommodation.

- Hotel prices are convenient

- Hotel staff is willing to respond to your request.

- Hotel rooms are Clean and hygienic.

- Discipline and flexibility of staff

- Speed check in to the airport.

- Speed check in to the airport.

- Speed check out from the airport

- Doors are automatically operated.

- Bus seats for limited mobility are next to the entrance and exit doors and in close proximity to the stopping place of the vehicle.

- Almost step-free accessibility of toilets and service areas with almost no thresholds minimal

- Buses are equipped with handholds and other gripping aids.

- Stairs are low step height to guarantee accessibility.

- Ramps with handrails at the tourist sites.

- Availability of Tourist guide book.

- Product signs in stores.

- Quality of information on things to do.

- Availability of pamphlet for each sightseeing.

- Promotion matches reality.
-Prices of food and beverages are convenient.

- Interaction with restaurant staff.

- Friendliness of hotel staff.

- Quality of public announcements.

- Terminal temperature/air conditioning.

- Overall attitude of staff.

- Staff appearance.

-the entertainment services and Arts that provided.

- Value for money in general.

- Friendliness of the local population. 


\section{Low perception}

-food and beverages hygiene.

- Standard of transport services.

- Public transportation station exit signs.

- Interaction with taxi drivers.

- Lodging facilities signs.

- Accuracy of the answers you receive at your request.

- Problems due to lack of understanding of language.

- Flight information Display system (FIDS).

- Cleanliness of restrooms.

-Security/airport safety.

-Seating areas.

- Quality of food and beverage.

- Duty free level.

- the Behavioral patterns consistent with your social habits

- Tourist services provided satisfy your motives and wants.

- Inherited traditions of Egyptian society do not prevent your enjoyment of visit There is cultural diversity in Cairo.

- Expectations are regularly assessed via market survey.

- Cleanliness of bathing areas

- Tourist sign maps.

- Lack of communication due to language barrier.

- Level of crowding.

- Cleanliness of the local environment.

- Quality of air in the destination.

- Feeling of security and safety.
-Variety and quality of places to eat and drink In.

High perception

- Restaurants provide food and beverage that you used to have in your daily life.

- Terminal atmosphere/comfort.

- There is cultural diversity in Cairo.

\section{Low expectation}

Shape (2) expectation-satisfaction grid

Placing of each attribute on an expectation-satisfaction grid was accomplished by using the percentages of expectation and satisfaction as the coordinates. Each attribute on the grid could then be analyzed by locating the appropriate quadrant in which it fell. For example, the top left quadrant contains attributes that had high expectation but low perception. Attributes in the top right quadrant were rated very satisfied, where levels of expectation and perception were high. Attributes in the bottom left quadrant were considered less satisfied, where both the expectation and perception levels are low. Finally, attributes in the bottom right quadrant were satisfying, because they were rated low expectation but the perception rated high.

According to the results shown the shapes expectation-satisfaction grid where the items with high expectation and high perception(upper right-hand quadrant) were: Prices of food and beverages are convenient, Interaction with restaurant staff ,Friendliness of hotel staff, Quality of public announcements, Terminal temperature/air conditioning, Overall attitude of staff, Staff appearance, entertainment services and Arts provided, Value for money in general and Friendliness of the local population . Items with low perception and high expectation (upper left-hand quadrant) were: Restaurants provide correct account lists, Accessibility to tourist attractions ,Public transportation signs, Quality of accommodation ,Hotel prices are convenient, Hotel staff are willing to respond to your request ,Hotel rooms are Clean and hygienic, Discipline and flexibility of staff ,Speed check- in to the airport ,Speed check - in and out from the airport ,Doors are automatically operated, Bus seats for limited mobility are next to the entrance and exit doors and in close proximity to the stopping place 
of the vehicle ,Almost step-free accessibility of toilets and service areas with almost no thresholds or minimal, Buses are equipped with handholds and other gripping aids ,Stairs are a low- step height to guarantee accessibility , Ramps with handrails at the tourist sites, Availability of Tourist guide book ,and Product signs in stores, Quality of information on things to do ,Availability of pamphlet for each sightseeing and Promotion matches reality.

Items with low expectation and low perception(lower right-hand quadrant) were: Food and beverages hygiene , Standard of transport services, Public transportation station exit signs, Interaction with taxi drivers ,Lodging facilities signs, Accuracy of the answers you receive at your request ,Problems due to lack of understanding of language ,Flight information Display system (FIDS), Cleanliness of restrooms ,Security/airport safety ,Seating areas ,Quality of food and beverage ,Duty free level, the Behavioral patterns are consistent with your social habits, Tourist services provided satisfy your motives and wants ,Inherited traditions of Egyptian society do not prevent your enjoyment of visit ,There is cultural diversity in Cairo , Expectations are regularly assessed via market survey, Cleanliness of bathing areas, Tourist sign maps , Lack of communication due to language barrier, Level of crowding, Cleanliness of the local environment,Quality of air in the destination and Feeling of security and safety.

Items with low expectation and high perception (lower left-hand quadrant) were: Variety and quality of places to eat and drink In, Restaurants provide the food and beverage that you used to have in your daily life, Terminal atmosphere/comfort and there is cultural diversity in Cairo

\section{Tourist's overall Satisfaction Level:}

Table (5) shows the participants overall satisfaction level that ranged from (extremely dissatisfy to extremely satisfy.

Table (5) Tourists' Overall Level of Satisfaction

\begin{tabular}{|c|c|c|c|}
\hline & Percent & Valid Percent & $\begin{array}{c}\text { Cumulative } \\
\text { Percent }\end{array}$ \\
\hline $\begin{array}{l}\text { extremely dissatisfied } \\
\text { dissatisfied } \\
\text { Neutral } \\
\text { Salisfied } \\
\text { extremely satisfied } \\
\text { Total }\end{array}$ & $\begin{array}{r}3.5 \\
15.1 \\
23.3 \\
30.2 \\
3.5 \\
75.6 \\
100.0\end{array}$ & $\begin{array}{r}4.6 \\
20.0 \\
30.8 \\
40.0 \\
4.6 \\
100.0\end{array}$ & $\begin{array}{r}4.6 \\
24.6 \\
55.4 \\
95.4 \\
100.0\end{array}$ \\
\hline
\end{tabular}

Table (5) It seen from $44.6 \%$ of the participants indicated that they were satisfied and extremely satisfied with Cairo attributes but on the other hand $30.8 \%$ were neutral in their opinions and $4.6 \%$, and $20 \%$ of the respondents were dissatisfied, extremely dissatisfied. Respondents' overall perceived level of satisfaction tended toward satisfaction.

\section{Service provided and overall expectation:}


Table (6) services provided in Cairo

\begin{tabular}{|ll|r|r|r|}
\hline & Percent & Valid Percent & \multicolumn{1}{c|}{$\begin{array}{c}\text { Cumulative } \\
\text { Percent }\end{array}$} \\
\hline & Yes & 52.3 & 52.3 & 52.3 \\
Valid & No & 47.7 & 47.7 & 100.0 \\
& Total & 100.0 & 100.0 & \\
\hline
\end{tabular}

Table (6) shows that $52.3 \%$ of respondents think that the service provided in Cairo meets their overall expectation. Also almost $48 \%$ stated that it doesn't meet their overall expectation.

Future behavior of visitors of Cairo:

Table (7) Future behavior of visitors of Cairo

\begin{tabular}{|c|c|c|c|c|}
\hline & & Percent & Valid Percent & $\begin{array}{c}\text { Cumulative } \\
\text { Percent }\end{array}$ \\
\hline $\begin{array}{l}\text { Valid } \\
\text { Total }\end{array}$ & $\begin{array}{l}\text { recommend to others } \\
\text { say positive things } \\
\text { revisit Cairo in the } \\
\text { future } \\
\text { Other }\end{array}$ & $\begin{array}{r}16.9 \\
44.6 \\
23.1 \\
9.5 \\
100.0 \\
\end{array}$ & $\begin{array}{r}17.5 \\
46.0 \\
23.8 \\
9.5 \\
3.2 \\
100.0 \\
\end{array}$ & $\begin{array}{r}17.5 \\
63.5 \\
87.3 \\
96.8 \\
100.0\end{array}$ \\
\hline
\end{tabular}

The results table 7 indicated that $46 \%$ of respondents will say positive things about Cairo and $23.8 \%$ decided to revisit Cairo in the future.

\section{Differences among nationalities opinions}

Table (8) presents the differences among nationalities of tourists in their perception of services provided in Cairo as a tourist destination

Nationality differences: 
Table (8) differences among nationalities opinions

\begin{tabular}{|c|c|c|c|c|c|c|}
\hline Dimensions & Items & $\begin{array}{c}\text { Arabian } \\
1\end{array}$ & $\begin{array}{c}\text { European } \\
2\end{array}$ & $\begin{array}{c}\text { Fareast } \\
3\end{array}$ & $\begin{array}{c}\text { American } \\
4\end{array}$ & $\begin{array}{c}\text { Other } \\
\mathbf{5}\end{array}$ \\
\hline \multirow{6}{*}{$\begin{array}{l}\text { Eating and } \\
\text { drinking }\end{array}$} & $\begin{array}{l}\text { Restaurants provide correct } \\
\text { account lists }\end{array}$ & $\begin{array}{l}\text { strongly } \\
\text { disagree }\end{array}$ & neutral & neutral & agree & $\begin{array}{l}\text { strongly } \\
\text { agree }\end{array}$ \\
\hline & $\begin{array}{l}\text { Variety and quality of places to } \\
\text { eat and drink In }\end{array}$ & Neutral & agree & neutral & neutral & agree \\
\hline & food and beverages hygiene & disagree & disagree & disagree & disagree & agree \\
\hline & $\begin{array}{c}\text { Prices of food and beverages are } \\
\text { convenient }\end{array}$ & $\begin{array}{l}\text { strongly } \\
\text { agree }\end{array}$ & agree & agree & agree & agree \\
\hline & Interaction with restaurant staff & Neutral & neutral & neutral & agree & $\begin{array}{c}\text { strongly } \\
\text { agree }\end{array}$ \\
\hline & $\begin{array}{l}\text { Restaurants provide the food } \\
\text { and beverage that you used to } \\
\text { have in your daily life }\end{array}$ & neutral & disagree & neutral & neutral & agree \\
\hline \multirow{5}{*}{ Transportation } & $\begin{array}{l}\text { Accessibility to tourist } \\
\text { attractions }\end{array}$ & disagree & neutral & disagree & disagree & neutral \\
\hline & Public transportation signs & disagree & disagree & disagree & disagree & neutral \\
\hline & Standard of transport services & neutral & neutral & disagree & disagree & neutral \\
\hline & $\begin{array}{l}\text { Public transportation station exit } \\
\text { signs }\end{array}$ & neutral & disagree & disagree & disagree & neutral \\
\hline & Interaction with taxi drivers & Agree & neutral & disagree & neutral & neutral \\
\hline \multirow{6}{*}{ accommodation } & Lodging facilities signs & disagree & neutral & neutral & agree & agree \\
\hline & Quality of accommodation & disagree & neutral & neutral & neutral & agree \\
\hline & Friendliness of hotel staff & neutral & neutral & agree & agree & agree \\
\hline & Hotel prices are convenient & Neutral & neutral & neutral & agree & agree \\
\hline & $\begin{array}{l}\text { Hotel staff are willing to } \\
\text { respond to your request }\end{array}$ & neutral & neutral & agree & agree & agree \\
\hline & $\begin{array}{c}\text { Hotel rooms are Clean and } \\
\text { hygienic }\end{array}$ & neutral & agree & neutral & agree & agree \\
\hline
\end{tabular}




\begin{tabular}{|c|c|c|c|c|c|c|}
\hline & $\begin{array}{l}\text { Discipline and flexibility of } \\
\text { staff }\end{array}$ & Neutral & neutral & neutral & agree & agree \\
\hline \multirow{15}{*}{ Airport } & Speedy check in to the airport & $\begin{array}{l}\text { strongly } \\
\text { disagree }\end{array}$ & neutral & neutral & neutral & agree \\
\hline & $\begin{array}{l}\text { Speedy check out from the } \\
\text { airport }\end{array}$ & disagree & neutral & neutral & neutral & neutral \\
\hline & $\begin{array}{l}\text { Accuracy of the answers you } \\
\text { receive at your request }\end{array}$ & disagree & neutral & neutral & neutral & agree \\
\hline & $\begin{array}{l}\text { Problems due to } \\
\text { miscommunication }\end{array}$ & Agree & neutral & neutral & neutral & neutral \\
\hline & $\begin{array}{l}\text { Flight information Display } \\
\text { system (FIDS) }\end{array}$ & disagree & neutral & neutral & agree & neutral \\
\hline & $\begin{array}{l}\text { Quality of public } \\
\text { announcements }\end{array}$ & Neutral & neutral & agree & agree & neutral \\
\hline & Terminal atmosphere/comfort & Agree & neutral & agree & agree & neutral \\
\hline & $\begin{array}{l}\text { Terminal temperature/air } \\
\text { conditioning }\end{array}$ & Neutral & neutral & agree & agree & neutral \\
\hline & Cleanliness of restrooms & Neutral & neutral & neutral & agree & neutral \\
\hline & Overall attitude of staff & disagree & neutral & neutral & neutral & neutral \\
\hline & Staff appearance & Neutral & neutral & neutral & agree & agree \\
\hline & Security/airport safety & Agree & agree & neutral & neutral & disagree \\
\hline & Seating areas & Neutral & agree & neutral & neutral & neutral \\
\hline & Quality of food and beverage & disagree & neutral & neutral & neutral & neutral \\
\hline & Duty free level & Neutral & neutral & neutral & neutral & agree \\
\hline \multirow[b]{2}{*}{$\begin{array}{c}\text { Accessibility to } \\
\text { limited } \\
\text { mobility }\end{array}$} & $\begin{array}{l}\text { Doors are operated fully } \\
\text { automatically }\end{array}$ & disagree & neutral & neutral & neutral & neutral \\
\hline & $\begin{array}{l}\text { Bus seats for limited mobility } \\
\text { are next to the entrance and exit } \\
\text { doors and in close proximity to } \\
\text { the stopping place of the } \\
\text { vehicle }\end{array}$ & disagree & neutral & neutral & agree & neutral \\
\hline
\end{tabular}




\begin{tabular}{|c|c|c|c|c|c|c|}
\hline & $\begin{array}{l}\text { Almost step-free accessibility of } \\
\text { toilets and service areas with } \\
\text { almost no threhols or minimal.. }\end{array}$ & disagree & neutral & neutral & neutral & neutral \\
\hline & $\begin{array}{c}\text { Buses are equipped with } \\
\text { handholds and other gripping } \\
\text { aids }\end{array}$ & disagree & neutral & disagree & neutral & neutral \\
\hline & $\begin{array}{l}\text { Stairs are a low step height to } \\
\text { guarantee accessibility }\end{array}$ & $\begin{array}{l}\text { strongly } \\
\text { disagree }\end{array}$ & neutral & neutral & disagree & neutral \\
\hline & $\begin{array}{c}\text { Ramps with handrails in the } \\
\text { tourist sites }\end{array}$ & $\begin{array}{l}\text { strongly } \\
\text { disagree }\end{array}$ & disagree & neutral & neutral & neutral \\
\hline \multirow{5}{*}{ Culture } & $\begin{array}{l}\text { entertainment services and Arts } \\
\text { that are provided }\end{array}$ & agree & agree & agree & $\begin{array}{l}\text { strongly } \\
\text { agree }\end{array}$ & neutral \\
\hline & $\begin{array}{c}\text { the Behavioral patterns are } \\
\text { consistent with your social } \\
\text { habits }\end{array}$ & neutral & neutral & neutral & neutral & neutral \\
\hline & $\begin{array}{c}\text { tourist services provided satisfy } \\
\text { your motives and wants }\end{array}$ & neutral & neutral & neutral & agree & neutral \\
\hline & $\begin{array}{l}\text { Inherited traditions of Egyptian } \\
\text { society do not prevent your } \\
\text { enjoyment of visit }\end{array}$ & disagree & neutral & neutral & neutral & neutral \\
\hline & $\begin{array}{l}\text { There is cultural diversity in } \\
\text { Cairo }\end{array}$ & agree & agree & neutral & agree & agree \\
\hline $\begin{array}{l}\text { Value for } \\
\text { money }\end{array}$ & Value for money in general & neutral & neutral & neutral & agree & agree \\
\hline $\begin{array}{c}\text { Pre-arrival } \\
\text { communication }\end{array}$ & $\begin{array}{l}\text { Expectations are regularly } \\
\text { assessed via market survey }\end{array}$ & $\begin{array}{l}\text { strongly } \\
\text { disagree }\end{array}$ & disagree & disagree & disagree & neutral \\
\hline $\begin{array}{c}\text { Bathing water } \\
\text { qualities }\end{array}$ & Cleanliness of bathing areas & neutral & neutral & disagree & neutral & agree \\
\hline \multirow{4}{*}{ Information } & $\begin{array}{c}\text { Availability of Tourist guide } \\
\text { book }\end{array}$ & $\begin{array}{l}\text { strongly } \\
\text { disagree }\end{array}$ & neutral & disagree & disagree & agree \\
\hline & Tourist sign maps & $\begin{array}{l}\text { strongly } \\
\text { disagree }\end{array}$ & neutral & disagree & disagree & neutral \\
\hline & Product signs in stores & $\begin{array}{l}\text { strongly } \\
\text { disagree }\end{array}$ & neutral & disagree & disagree & neutral \\
\hline & Quality of information on things & neutral & agree & neutral & neutral & neutral \\
\hline
\end{tabular}




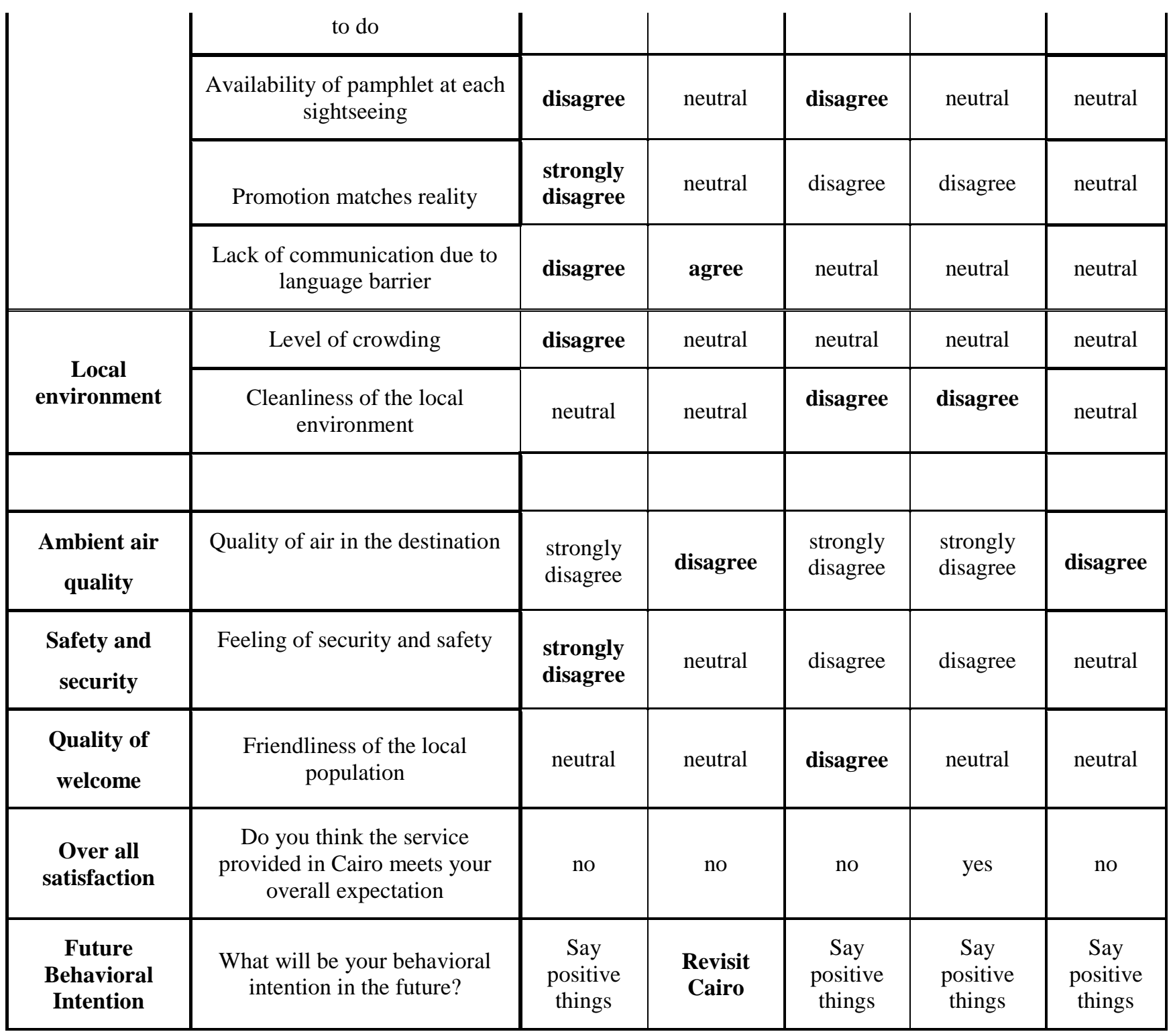

The results presented in table (8) show that respondents from different nationalities are different in their perception to the attributes of Cairo as a tourist destination. Therefore, it can be concluded that hypothesis 2 is supported, which stated that "there is a difference among nationalities in their perception in regard to Cairo as a tourist destination".

\section{But on the other hand their opinions are almost similar regarding the following items:}

- food and beverages hygiene

- Prices of food and beverages are convenient

- the Behavioral patterns are consistent with your social habits

- Public transportation signs

- $\quad$ Problems due to miscommunication

- Cleanliness of restrooms

- Seating areas

- Quality of food and beverage 
- $\quad$ Duty free level

- $\quad$ Doors are automatically operated

- Almost step-free accessibility of toilets and service areas with almost no thresholds or minimal

- $\quad$ tourist services provided satisfy your motives and wants

- Inherited traditions of Egyptian society do not prevent your enjoyment of visit

- $\quad$ There is cultural diversity in Cairo

- $\quad$ Level of crowding

- Do you think the service provided in Cairo meets your overall expectation

- $\quad$ Speedy check out from the airport

- Tourist behavioral intention in the future is positive.

\section{Chi-square test:}

- $\quad$ Chi- square test is utilized here to find out if there is a dependency or independency between two variables ( the service provided in Cairo meets your overall expectation, and the behavioral intention in the future)

Table (9) Chi-square test

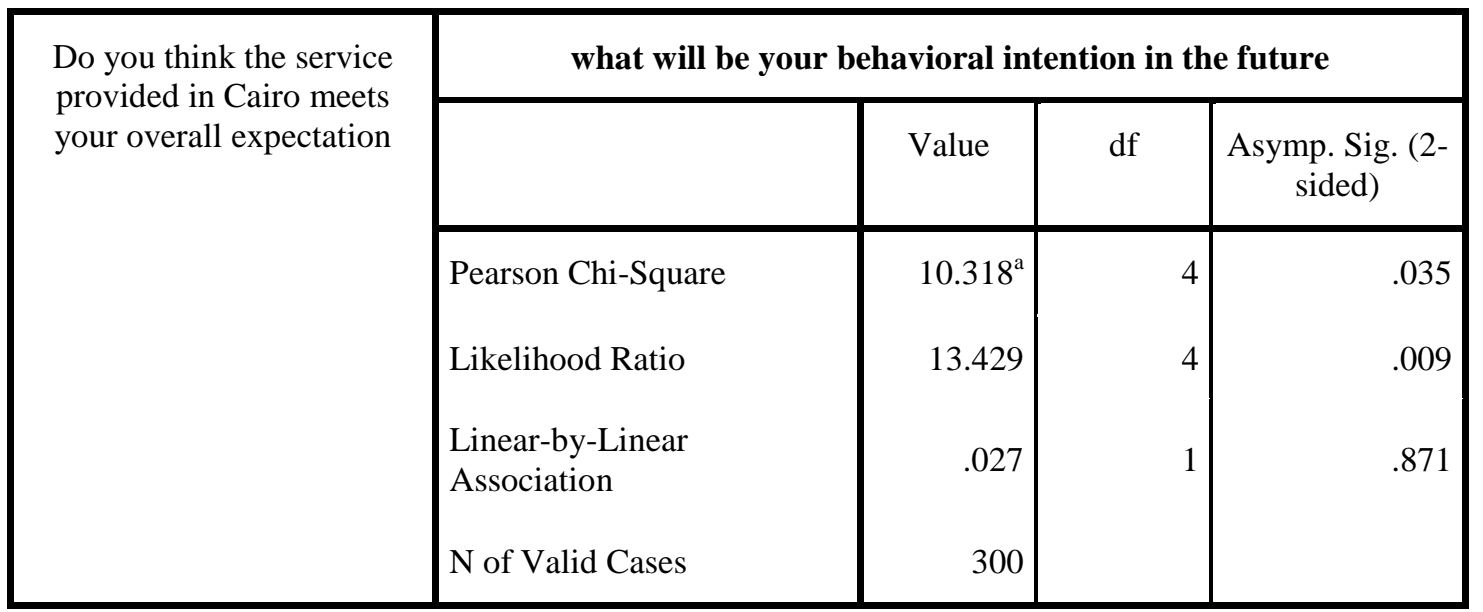

a. 4 cells $(40.0 \%)$ have expected count less than 5 . The minimum expected count is .92 .

According to Table (9) P.Value equals 0.035 that is less than 0.05 so the alternative hypothesis "there is no independence between services provided in Cairo that meets overall expectation and behavioral intention in the future" is accepted, and thereby proved is hypothesis no. 3 "The tourists' behavioral intention in the future is dependent on services provided in Cairo that meets overall expectation"

\section{Conclusion and Recommendation:}

\section{conclusions}

The results of this study validate the research hypothesis that there is a gap between what tourists expected and perceived. Therefore, the government and tourism authority side by side with tourist services suppliers should focus on eliminating this 
gap, improve and maintain the facilities in order to attract more tourists and to fulfill the overall satisfaction of tourists during their visit. For example: sources of information, local environment, transportation, accessibility for limited mobility, ambient air quality, bathing water qualities accommodation, pre-arrival communication, eating and drinking places, airport, value for money, culture, safety and security, all of them should be maintained and improved properly. Also, Tourists were, satisfied with the prices of food and beverages are convenient, Quality of public announcements at the airport, level of Terminal atmosphere/comfort, entertainment services and Arts provided and Friendliness of the local population

Furthermore, the study classified high-perception and high expectation attributes, low perception and high expectation attributes, low-perception and high expectation attributes, and low-perception and low-expectation attributes through expectation-satisfaction. This classification will assist tourism marketers and planners to enhance strengths and improve and develop weaknesses.

This study indicated a difference among nationalities of tourists regarding their perception of services provided in Cairo as a tourist destination, but they are almost similar in their perception of the food and beverages hygiene. Prices of food and Almost beverages are convenient ,the Behavioral patterns are consistent with your social habits ,Public transportation signs ,Problems due to miscommunication, cleanliness of restrooms, Seating areas at the airport, Quality of food and beverage provided, level of Duty free level, Doors are operated fully automatically for people with limited mobility, step-free accessibility of toilets and service areas with almost no thresholds or minimal for people with limited mobility , the tourist services provided satisfy their motives and wants, Inherited traditions of Egyptian society do not prevent their enjoyment of the visit. There is cultural diversity in Cairo, the Level of crowding, the service provided in Cairo meets their overall expectation, speedy check- out from the airport, tourist behavioral intention in the future is positive.

The differences among nationalities' opinions will help to encourage and raise awareness concerning the importance and necessity of improving and enhance the level of tourist satisfaction. as tourists today are highly sensitive to the quality of service they receive, (Canny,2013) Thus, in order to create effective strategies to enhance and improve the services provided, it's necessary to understand the tourists who visit a destination.

The study revealed that the tourists' behavioral intention in the future is dependent on services provided in Cairo that meets over all expectation. Once tourists perceive their expectation though services provided their satisfaction will rise and so will their behavioral intention in the future.

\section{Recommendation:}

Further research can be developed in other tourism destinations or can be applied to different hotel categories by measuring service quality, tourist satisfaction and future behavioral intention for providing richer results for analysis in the academic study. It is recommended that further research could use the qualitative research method whether in-depth interviews, focus groups, or a combination of both.

\section{Reference:}

1. Aksu,A., İçigen, T. E.and Ehtiyar,R (2010) A Comparison of Tourist Expectations and Satisfaction: A Case Study from Antalya Region of Turkey,14(2), 66-77

2. Alén González, M. E.; Rodríguez Comesaña, L. and Fraiz Brea, J. A. (2007). Assessing tourists behavioral intentions through perceived service quality and customer satisfaction .Joural of Business Research , 60(2)153-160

3. Armario,M.E (2008) Tourist satisfaction an analysis of its antecedents . Universidad, Sociedad y Mercados Globales, 367-382

4. Berry, L. and Parasuraman, A. (1991). Marketing Services: Competing through Quality

New York, Free Press.

5. Bosque, I.R.D. and Martin, H.S. (2008). Tourism satisfaction: A cognitive-affective model. Annals of Tourism Research, 35 (2), 551-573.

6. Bowen, D. and Clarke, J., 2002. Reflection on Tourists Satisfaction Research: Past, Present and Future. Journal of Vacation Marketing, 8(4), 297-308

7. Buhalis, D. (2000) Marketing the competitive destination of the future, Tourism Management, 21 (1), 97-116. 
8. Canny, U.I. (2013) An Empirical Investigation of Service Quality, Tourist Satisfaction and Future Behavioral Intentions among Domestic Local Tourist at Borobudur Temple. International Journal of Trade, Economics and Finance, 4(2),86-91

9. Cronin, J.J., Brady, M.K., Hult, G.T.M.(2000) Assessing the effects of quality, value, and customer satisfaction on consumer behavioral intentions in service environments, Journal of Retailing, 76 (2), 193-218

10. Cugelman.B., Thelwall,M. and Dawaes, P. (2009). The dimensions of website credibility and their relation to active trust and behavioral impact. communications of the association for information systems, 24, 455-472

11. East,R.; Wrighr,M .and Vanhuele,M. (2008) Consumer Behaviour in application in marketing .london ,Sage .pp.166

12. European Communities( 2003) A Manual for Evaluating the Quality Performance of Tourist Destinations and Services. Available at :

http://ec.europa.eu/enterprise/sectors/tourism/files/studies/evaluation_quality_performance/qualitest_manual_en.pd [ accessed 10-5-2015]

13. Gibson, H. (2005) Towards an understanding of „why sport tourists do what they do”, Sport in Society, Special Issue: Sport Tourism: Concepts and Theories, 8 (2), 198-217

14. Grönroos, C.( 1983) Strategic management and marketing in the service sector, Boston, Marketing Science Institute.

15. Gursoy, D.; McCleary, K. W. and Lepsito, L. R. (2007). "Propensity to complain: affects of personality and behavioral factors.” Journal of Hospitality \& Tourism Research, 31 (3), 358-386.

16. Gyimothy,S.(2000).Odysseys:Analysing service journeys from the customer'sperspective. Managing Service Quality, 10(6), 389-396.

17. Jafari, J. (2000) Encyclopedia of Tourism, London: Routledge.

18. Kuenzel, S. and Katsaris, N. (2009). A critical analysis of service recovery processes in the hotel industry. TMCAcademic Journal, 4(1), 14-24.

19. Lovelock, C. H., Patterson, P. G. and Walker, R. H. (2001). Services Marketing: An Asia-Pacific Perspective, $2^{\text {nd }}$ Ed. Australia: Prentice Hall.

20. Mahadzirah, M., Ahmad, R. A., and Safiek, M. (2012). Tourist's evaluations of destination image and future behaviour intention: the case of Malaysia. Journal of Management and Sustainability, 2(1), 181-189.

21. Paunovic, Ivan (2014) Satisfaction Of Tourists In Serbia, Destination Image, Loyalty and Dmo Service Quality. European Journal of Tourism, Hospitality and Recreation .special issue , 163-181

22. Seakhoa-King ,A. (2007) Conceptualising quality of a tourism destination: An investigation of the attributes and dimensions of quality of a tourism destination. Un published Ph.D. thesis. University of Bedfordshire

23. Terzibasoglu, E. (2004) 'Successful destination management and marketing fundamentals', Conference On Destination Marketing for the 21st Century, Moscow, 23 March. TURIZAM ,14( 2 ) 66-77

24. Vengesayi,S (2003) A Conceptual Model Of Tourism Destination Competitiveness And Attractiveness. Anzmac Conference Proceedings Adelaide 1-3 December.PP.637-647

25. Weiermair, K. (2000) Tourists' perceptions towards and satisfaction with service quality in cross-cultural service encounter: Implications for hospitality and tourism management, Managing Service Quality, 10(6) 397-409.

26. Yoon, Y. and Uysal, M. (2005) An Examination of the Effects of Motivation and Satisfaction on Destination Loyalty: A Structural Model. Tourism Management. 26(1),45-56. 


\section{قياس الفجوات بين التوقع و الإدراك لدى السياح بالتطبيق على القاهرة كمقصد سياحى}

\section{الملخص}

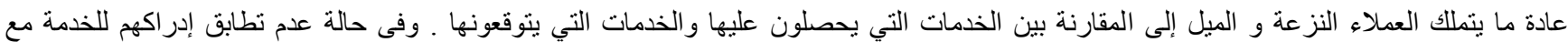

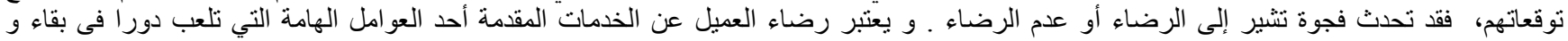

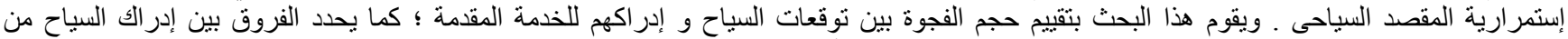

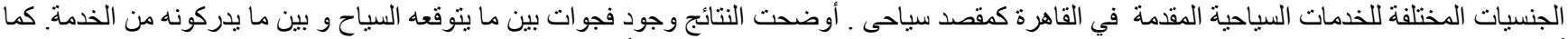

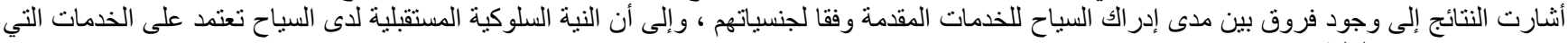

الكلمات الدالة :المقصد السياحى، جودة المنتج السياحى ، رضاء السائح ، النية السلوكية المستقبلية 